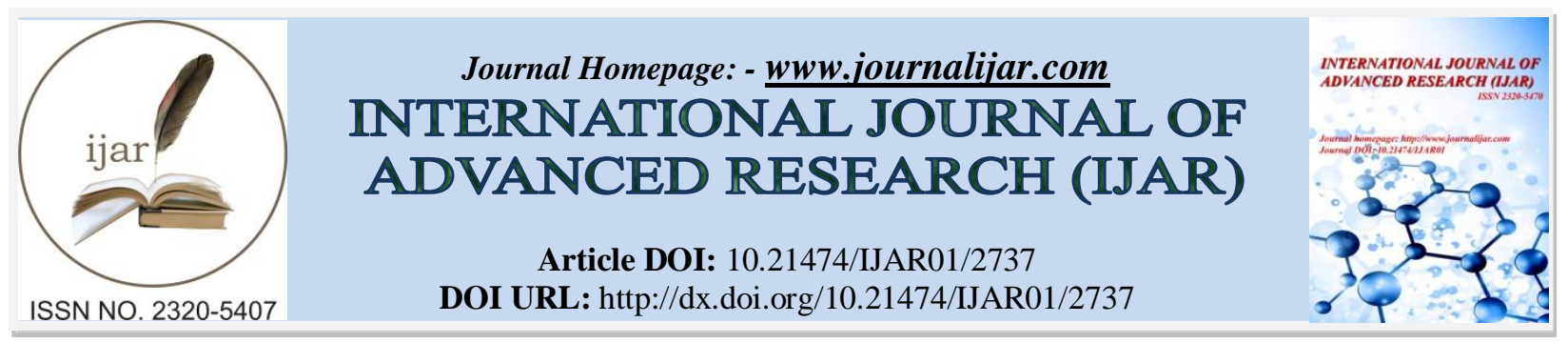

\title{
RESEARCH ARTICLE \\ DETERMINATION AND QUANTIFICATION OF FLAVONOIDS AND PHENOLIC CONTENT OF WRIGHTIA TINCTORIA R.BR.
}

Bhagwan M. Waghmare and Rahul K. Dhabale

Botany Research Centre, Department of Botany, Maharashtra Mahavidyalaya, Nilanga. Dist. Latur (M.S.) India.

\begin{abstract}
Manuscript Info
Manuscript History

Received: 15 November 2016

Final Accepted: 17 December 2016

Published: January 2017

Key words:-

Wrightia tinctoria, Rutin, Catechol, flavonoids.

\section{Abstract}

Wrightia tinctoria have been studies for their chemical constituents. The powder of fruit of $W$. tinctoria was subjected to hot extraction with methanol, petroleum ether and ethyl acetate and subjected to chromatography. The flavonoids in form of Rutin and Catechol were isolated from fruit extract of $W$. tinctoria. The results revealed that, methanol fruit extracts of $W$. tinctoria contains maximum amount of flavonoids as $90 \mathrm{mg} / \mathrm{g}$ of Rutin equivalent and the phenolic content as $3.0 \mathrm{mg} / \mathrm{g}$ of Catechol equivalents. While, fruit extract of ethanol and petroleum ether has been found minimum, whereas, fruit extract of $W$. tinctoria was found highest presence of catechol equivalents.
\end{abstract}

Copy Right, IJAR, 2016,. All rights reserved.

\section{Introduction:-}

India. (Kirtikar and Basu, 1994; Naik 1998, Wadood Khan 1985, Zate B. R. 1983, S. R. Shinde 2008).

The whole plant and its specific parts such as, bark, leaf, seed fruits, roots are known to have high medicinal properties have a back history of use indigeneous communities in India. (Nadkarni K. M., 1976).

The medicinal value of $W$. tinctoria for the treatment of a large number common ailments of human being which were reported in Ayurveda, Siddha, Unani and folk medicine (Kirtikar and Basu 1975, Warrier et.al. 1996) and screening of scientific data revealed that a large number of various drugs of indigeneous drug have been investigated (Khare C. P. 2007 and Niir board 2008).

Apart from that, W. tinctoria also provide comprehensive information on the traditional use of mankind. Such as, ethnopharmacology, phytochemistry and pharmacological study. Present study helpful to determination and quantity content of flavonoids and phenolic compounds such compounds is useful for producing safer drugs for the treatment of common various ailments of human beings (Bharat N. S. 2015).

\section{Materials and Methods:-}

\section{Determination of flavonoids from fruits extracts of Wrightia tinctoria $R$.Br:-}

Rutin was used as standard flavonoid. Different concentrations (20 to $100 \mu \mathrm{g} / \mathrm{ml})$ of rutin were analyzed at 510 $\mathrm{nm}$ and a calibration curve was plotted as absorbance versus concentration. $10 \mu \mathrm{g} / \mathrm{ml}$ of each test substance (Extracts of Wrightia tinctoria R.Br. was analyzed by using the similar procedure and quantity of flavonoids in mg per gram of rutin equivalent was determined for each extract.

Corresponding Author:- Bhagwan M. Waghmare.

Address:- Botany Research Centre, Department of Botany, Maharashtra Mahavidyalaya, Nilanga. Dist. 


\section{Procedure:-}

$>$ Known volume of samples was pipetted out in series of test tubes and volume was made up to $0.5 \mathrm{ml}$ with distilled water.

$>$ Sodium nitrite $(5 \% ; 0.03 \mathrm{ml})$ was added to each tube and incubated for 5 minutes at room temperature.

$>$ Aluminum chloride solution $(10 \% ; 0.6 \mathrm{ml})$ was added and incubated for 5 minutes at room temperature.

$>$ Sodium hydroxide solution $(1 \mathrm{M} ; 0.2 \mathrm{ml})$ was added and total volume was made up to $1 \mathrm{ml}$ with distilled water.

$>$ Absorbance was measured at $510 \mathrm{~nm}$ against a reagent blank.

$>$ Standard curve using different concentrations of rutin was prepared.

$>$ From the standard curve, concentration of flavonoids in the test samples was determined and expressed as $\mu \mathrm{g}$ of rutin equivalent.

\section{Determination of Phenolic compounds from fruit extracts of Wrightia tinctoria R.Br:-}

Catechol was used as standard phenolic compound. Different concentrations $(0.5$ to $2.5 \mu \mathrm{g} / \mathrm{ml})$ of catechol were analyzed at $650 \mathrm{~nm}$ and a calibration curve was plotted as absorbance versus concentration. $1 \mu \mathrm{g} / \mathrm{ml}$ of each test substance (extracts of Wrightia tinctoria $R . B r$. were analyzed by using the similar procedure and quantity of phenolic compounds in $\mathrm{mg}$ per gram of catechol equivalent was determined for each extract.

\section{Procedure:-}

$>$ Aliquot of each sample was pipette out in series of test tubes and volume was made up to $3 \mathrm{ml}$ with distilled water.

$>$ Folin-Ciocalteu Reagent $(0.5 \mathrm{ml})$ was added to each tube and incubated for 3 minutes at room temperature.

$>$ Sodium carbonate $(20 \% ; 2 \mathrm{ml})$ solution was added, mixed thoroughly and the tubes were incubated for 1 minute in boiling water bath.

$>$ Absorbance was measured at $650 \mathrm{~nm}$ against a reagent blank.

$>$ Standard curve using different concentrations of standard phenolic catechol was prepared.

$>$ From the standard curve, concentration of phenols in the test samples was determined and expressed as $\mu \mathrm{g}$ of catechol equivalent.

\section{Results and Discussion:-}

Determination of flavonoids:-

In order to investigate quantity of flavonoids by using absorbance of different concentrations (20 to $100 \mu \mathrm{g} / \mathrm{ml}$ ) of Rutin and the results are summarized in the table- 1. A calibration curve shows linear correlation at measured concentrations. Table- 2 represents the quantity of flavonoids in $\mathrm{mg}$ per gram of Rutin equivalent determined for test extract. The results indicate that methanol fruit extracts of W. tinctoria $R . B r$ was contain maximum amounts of flavonoids as $90 \mathrm{mg} / \mathrm{g}$ and 88 $\mathrm{mg} / \mathrm{g}$ of Rutin equivalents while minimum amount of flavonoids was in extract of petroleum ether.

Table 1:- Absorbance table for different concentrations of rutin

\begin{tabular}{|c|c|c|}
\hline Sl. No. & Concentration of Rutin (in $\boldsymbol{\mu g})$ & Optical Density (at 510nm) \\
\hline 1 & Blank & 0.19 \\
\hline 2 & 20 & 0.35 \\
\hline 3 & 40 & 0.56 \\
\hline 4 & 60 & 0.74 \\
\hline 5 & 80 & 0.91 \\
\hline 6 & 100 & \\
\hline
\end{tabular}


Graph 1:- Calibration Curve for Rutin

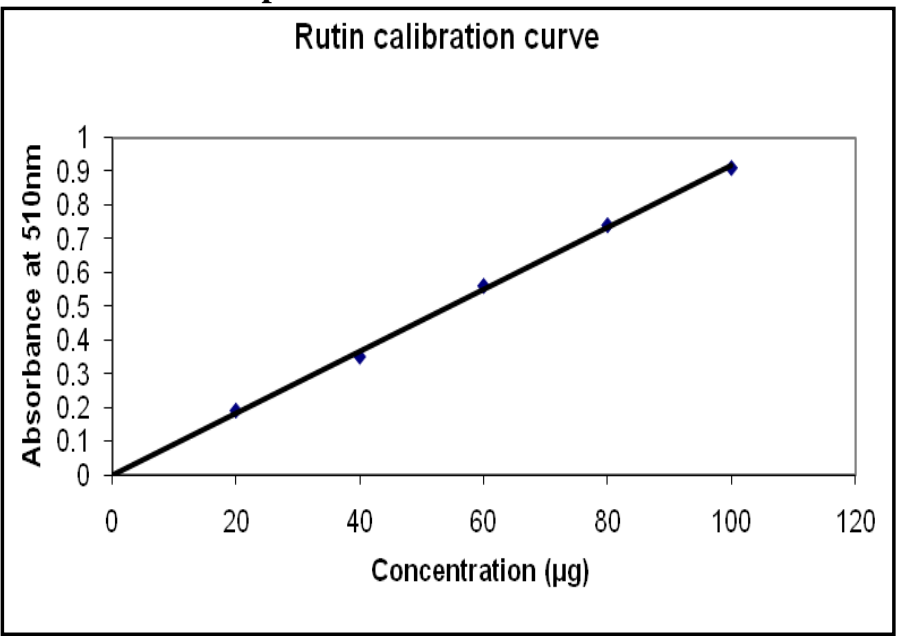

Table 2:- Quantity of Flavonoids (Rutin equivalents) found in each extract.

\begin{tabular}{|c|l|c|}
\hline $\begin{array}{c}\text { Sl. } \\
\text { No. }\end{array}$ & \multicolumn{1}{|c|}{ Test Sample } & $\mathbf{m g} / \mathbf{g}$ of Rutin equivalents \\
\hline 1 & Methanolic extract of W. tinctoria $R \cdot B r$ & $90 \mathrm{mg} / \mathrm{g}$ \\
\hline 2 & Petroleum ether extract of W. tinctoria $R \cdot B r$ & $14 \mathrm{mg} / \mathrm{g}$ \\
\hline 3 & Ethyl acetate extract of W. tinctoria $R \cdot B r$ & $22 \mathrm{mg} / \mathrm{g}$ \\
\hline
\end{tabular}

Determination of phenolic compounds:-

In order determine the quantity (quantum) of phenolic compounds by using the absorbance of different concentrations $(0.5$ to $2.5 \mu \mathrm{g} / \mathrm{ml})$ of Catechol and the results are given in the table- 3 . A calibration curve shows linear correlation at measured concentrations. Table- 4 represents the quantity of phenolic compounds in mg per gram of Catechol equivalent determined from the tested extracts. The results indicate that, ethyl acetate fruit extracts of W. tinctoria $R . B r$ contain maximum amounts of phenolic compounds as $3.0 \mathrm{mg} / \mathrm{g}$ and catechol equivalents. While, other tested extracts were found to be minimum. Among the tested samples ethyl acetate extracts of W. tinctoria R.Br was found to be highest count of Catechol equivalents.

Table 3:- Absorbance table for different concentrations of Catechol

\begin{tabular}{|c|c|c|}
\hline Sl. No. & Concentration of Catechol (in $\boldsymbol{\mu g})$ & Optical density (at 650nm) \\
\hline 1 & Blank & 0 \\
\hline 2 & 0.5 & 0.175 \\
\hline 3 & 1 & 0.325 \\
\hline 4 & 1.5 & 0.48 \\
\hline 5 & 2 & 0.64 \\
\hline 6 & 2.5 & 0.81 \\
\hline
\end{tabular}




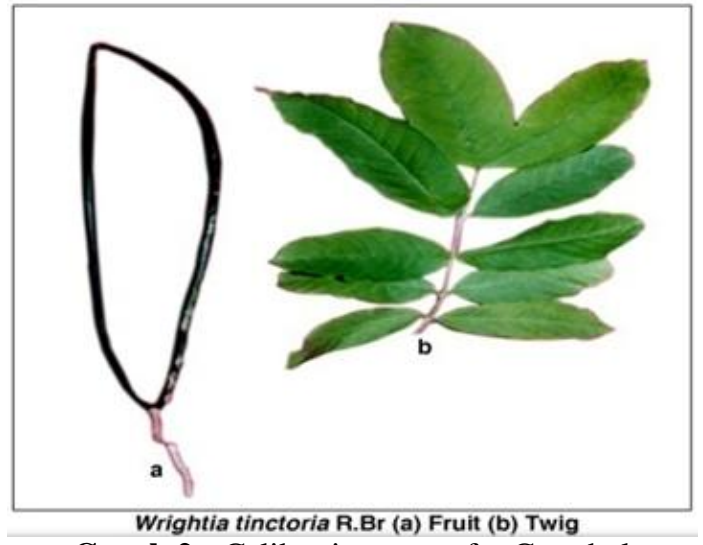

Graph 2:- Calibration curve for Catechol

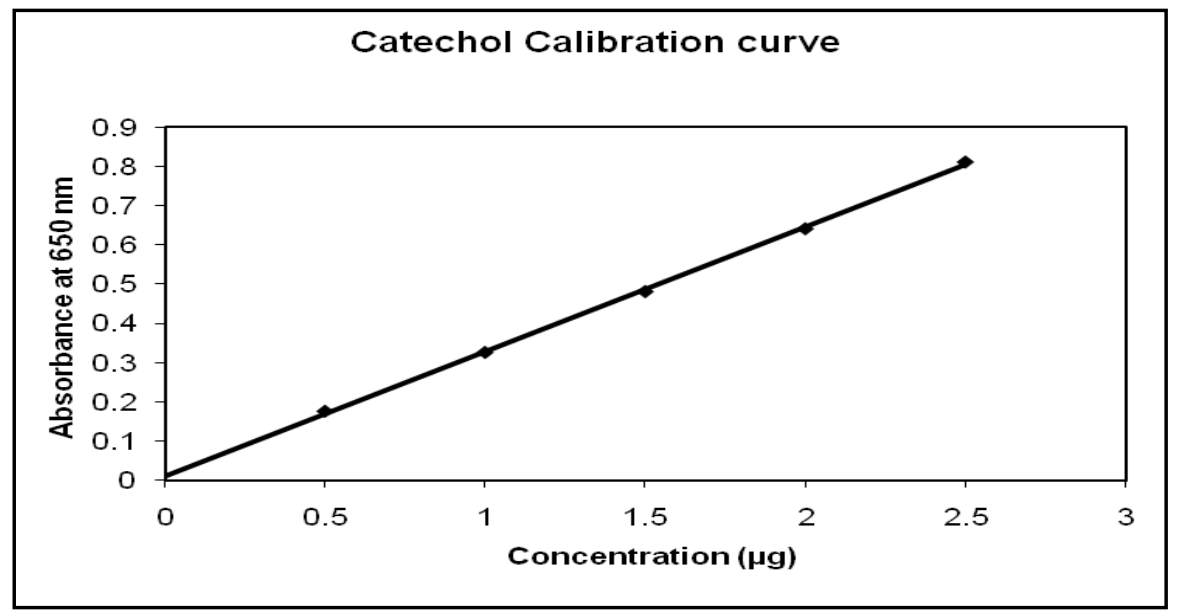

Table 4:- Quantity of phenolic compounds (Catechol equivalents) found in each extracts

\begin{tabular}{|c|l|c|}
\hline Sl. No. & \multicolumn{1}{|c|}{ Test sample } & mg/g of Catechol equivalents \\
\hline 1 & Methanolic extract of $W$. tinctoria $R \cdot B r$ & $2.25 \mathrm{mg} / \mathrm{g}$ \\
\hline 2 & Petroleum ether extract of W. tinctoria $R . B r$ & $1.0 \mathrm{mg} / \mathrm{g}$ \\
\hline 3 & Ethyl acetate extract of W. tinctoria $R . B r$ & $3.0 \mathrm{mg} / \mathrm{g}$ \\
\hline
\end{tabular}

\section{References:-}

1. Anonymous. The wealth of India. New Delhi: Publication and Information Directorate, CSIR; 1976, p. 588590.

2. Khare C. P. Indian Medicinal plants. Berlin/ Heidelbeg. Springer Science and Business Media, 2007, P. 720.

3. Kirtikar KR and Basu BD. Indian medicinal plants. Delhi: Jayyed Press; 1975, p. 1581.

4. Nadkarni KM. Indian material medica. Bombay: Popular Prakashan; 1976, p. 1296

5. Naik, V. N. (1998). Flora of Marathwada. vol. I, II. Amrut Prakashan, Aurangabad. Naik, V. N. (1998). Marathwadyatil samanaya vanoushadhi.

6. Shinde S.R. (2008) Ph.D. thesis submitted to Swami Ramanand Teerth Marathwada University, Nanded.

7. Wadood Khan, M.A. (1985). Flora of Bhokar and Hadgoan Range forests of Nanded district, Ph.D. thesis submitted to Marathwada University, Aurangabad.

8. Zate, B. R. (1983). Flora of Kinwat and Mahur Range forests of Nanded district. Ph.D. thesis submitted to Marathwada University, Aurangabad.

9. Niir board of consultants and Engineers, Handbook on Unani medicine with formulae, processes, use and analysis: Delhi National Institute of Industrial Research 2008. P. 170-177.

10. Warrier P. K., Nambiar V. P., Ramankutty C. Indian medicinal plants, Madras orient Langman ltd. 1996 p. 417-419. 